\title{
0 Poder Judicial na sociedade livre
}

\section{The Judiciary in a free society}

\section{esumo}

Nos dias atuais multiplicam-se as discussões em torno da "crise da justiça". Porém, nas sociedades modernas esta expressão (independentemente do seu conteúdo concreto) designa especificamente a crise da justiça democrática e liberal ou, pode-se ainda dizer, a crise do poder judicial na sociedade democrática e liberal. Assim, qualquer discussão acerca da "crise da justiça" parece exigir um enquadramento contextual que ajude a clarificar o lugar ocupado pelo poder judicial em sociedades como as nossas. O propósito deste artigo consiste em contribuir para elucidar qual é, do ponto de vista político e constitucional, esse contexto. A perspectiva da História do Pensamento Político é considerada como a mais útil, na medida em que permite aceder à origem dos fundamentos intelectuais que estruturam não só o poder judicial moderno, mas a sociedade moderna como um todo. Neste artigo, John Locke e Montesquieu aparecem como dois autores incontornáveis por terem dado um contributo indelével para essa dupla estruturação.

Palavras-chave: democracia, liberdade, poder judicial, poder executivo, cidadania.

\section{So bstract}

There is increasing debate about the "crisis of the judiciary", although in modern societies this expression (independent from its concrete content) specifically designates the crises of liberal democratic justice, or, it could be said, the crises of the judiciary in liberal and democratic society. Thus, any discussion about the "crisis of the judiciary" appears to demand a contextual framing that helps to clarify the place occupied by the judicial branch in societies such as ours. This article seeks to elucidate this context, from the political and constitutional point of view. The perspective of the History of Political Thinking is considered the most useful, to the degree to which it points to the origin of the intellectual foundation not only of modern judicial power, but of modern society as a whole. In this article, John Locke and Montesquieu are presented as two essential authors because they have made an indelible contribution to this dual structure.

Key words: democracy, liberty, judicial power, executive power, citizenship.

\section{Miguel Morgado}

Mestre em Sociologia e Ciência Política pela Universidade Católica PortuguesaUCP.

Professor na Faculdade de Ciências Humanas da UCP.

Neste artigo foi mantida a ortografia vigente em Portugal. 
Os conhecimentos que foram adquiridos em alguns países e que serão adquiridos em outros sobre as regras mais seguras que se possam seguir nos julgamentos criminais interessam mais o género humano do que qualquer outra coisa que exista no mundo.

Montesquieu

Do espirito das leis

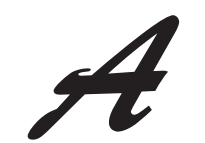

"crise da justiça" é uma expressão que parece ter adquirido direito de cidadania em quase todas as sociedades modernas, democráticas e liberais. Portugal e o Brasil não são excepção. Em cada discussão sobre o poder judicial, ou sobre a administração da justiça, perpassa um pressentimento generalizado de crise mais ou menos grave. Num livro publicado em Portugal no ano 2000, e que contou com a colaboração de alguns dos mais eminentes entendidos na matéria da crise da justiça, Jorge Miranda (2000, p. 253-254) aponta para a necessidade da compreensão de que "a crise da justiça não é só uma crise das instituições". Segundo Miranda, a "crise da justiça" é também "uma crise de valores da justiça" no contexto da relação do "sistema judiciário" com a "sociedade".

Tal sugestão obriga evidentemente ao exame da crise da justiça, não apenas do ponto de vista da "organização e do funcionamento do sistema judiciário", mas igualmente das relações deste sistema com a sociedade em geral, o que quer dizer que a ela só poderá começar a ser percebida com a análise do lugar do poder judicial na sociedade contemporânea, ou seja, na sociedade moderna, democrática e liberal.

No mesmo volume, um outro autor, Pedro Coutinho Magalhães (2000, p. 415), opta por tomar seriamente a necessidade de estudar o poder judicial no contexto do regime democrático e liberal. Conclui, ou, antes, sugere que a crise da justiça é agravada pela dificuldade do poder judicial em afirmar, em paridade com os outros poderes políticos, a sua legitimidade. Assim, parece que, "de todos os poderes estatais, o poder judicial é sempre o mais desfavorecido no acesso a estes caminhos para a (re)legitimação". De acordo com este autor, tal dificuldade deve-se também ao espartilho imposto por "um dos dogmas do pensamento político democrático", a saber, que "o poder judicial deverá ser «independente»". Ora, de acordo com o "pensamento político democrático", numa sociedade democrática a legitimação de qualquer poder político provém exclusivamente do "controlo popular". Logo, a contradição que ameaça a "(re)legitimação" necessária do poder judicial consiste na afirmação da sua independência em simultâneo com a confirmação de que se trata de um poder político democrático. A ser real, esta contradição pode ser fatal para o poder judicial, na medida em que a sua independência con- sagra a sua dignidade própria e o seu lugar particular na sociedade contemporânea.

Desta discussão promovida separadamente por Jorge Miranda e por Pedro Coutinho Magalhães percebe-se que a condição actual do poder judicial nunca será bem esclarecida se não revisitarmos os argumentos daqueles homens que o colocaram neste lugar particular no seio da sociedade moderna. A hora de crise nem sempre é a hora da lucidez, pois a pressão é para a resolução imediata dos problemas da superfície. Por vezes, a hora de crise recomenda o retorno à sabedoria de quem projectou o que se encontra ameaçado. No caso do poder judicial, a hora de crise é a hora de compreendermos as reflexões de um pensador como Montesquieu.

As discussões contemporâneas em torno da crise da justiça, independentemente das perspectivas que adoptam ou dos problemas concretas que visam solucionar, assumem consciente ou inconscientemente que a teoria do Estado que enquadra o sistema de justiça foi definitivamente afirmada. Essa suposição gera o efeito perverso de vedar aos intervenientes dessas discussões as ligações profundas entre, por um lado, o lugar ocupado pelo poder judicial nas teorias do Estado moderno, democrático e liberal, e, por outro lado, os caminhos de superação da(s) crise(s) da justiça. O diagnóstico dos defeitos ou lacunas do "sistema de justiça" não está separado da ideia de sociedade livre que temos. O que está efectivamente em "crise" no "sistema de justiça" depende do lugar político e social no qual queremos colocar o poder judicial. O propósito do pequeno comentário que se segue é, portanto, situar o debate acerca do poder judicial no contexto das teorias do Estado que contribuíram (intelectualmente falando) para a formação da nossa sociedade moderna, democrática e liberal. Em primeiro lugar, procurarei recuperar, através de John Locke e Montesquieu, o aparecimento do poder judicial enquanto poder político autónomo, e mostrar como essa afirmação histórica está intimamente relacionada com a defesa de um certo tipo de sociedade e de cidadania. De seguida, tentarei reproduzir as reflexões de Montesquieu sobre os limites e perigos do poder judicial, bem como a protecção que se deve garantir a esse poder. Posteriormente, intentarei demonstrar como esta concepção do poder judicial adequa-se a um certo tipo de cidadania e, por sua vez, ajuda a informar essa mesma cidadania.

\section{Locke e o Poder Executivo}

A reflexão abrangente sobre o poder judicial é iniciada por Montesquieu num contexto muito preciso. Na sua grande obra, O espirito das leis, Montesquieu (2000) oferece a sua teoria, digamos assim, do poder judicial no mesmo momento em que apresenta a sua teoria da liberdade, da 
separação de poderes e do regime inglês. Todos estes temas estão profundamente ligados no pensamento político de Montesquieu. Podemos dizer que a teoria do poder judicial em Montesquieu decorre da sua teoria da liberdade e da separação de poderes. É curioso notar quão tarde na história do pensamento político aparece o poder judicial como elemento autónomo de reflexão, especialmente se tivermos em conta que em meados do século XVIII já abundavam teorias da liberdade e havia já formulações várias da separação de poderes.

Tomemos como exemplo o caso de John Locke, um pensador político intimamente familiarizado com as práticas inglesas, as quais, embora na sua época ainda não estivessem completamente amadurecidas, forneceram também a Montesquieu um contexto de reflexão. No pensamento político de Locke é introduzida uma das primeiras formulações da teoria da separação de poderes (LOCKE, 1999). Porém, os três poderes que Locke distingue e divide são o poder executivo, legislativo e federativo. O poder judicial está ausente da separação de poderes de Locke. A razão para tal omissão encontra-se na doutrina lockeana do estado de natureza de onde decorrem todos os poderes políticos. Na verdade, os poderes constituídos na sociedade política são derivados da relação do indivíduo com os outros indivíduos, e com a lei natural, nesse estado de natureza que precede intelectualmente o Estado organizado. No estado de natureza, o indivíduo está submetido à lei natural, mas não existe nenhuma autoridade centralizada e reconhecida que aplique os seus preceitos. O poder para executar essa lei está entregue a cada um dos indivíduos. Essa é a condição necessária para que, na concepção de Locke, a lei natural possa ser efectivamente uma lei, "porquanto a lei natural seria, bem como todas as outras leis que dizem respeito aos homens neste mundo, de nenhum efeito, se não houvesse pessoa que, no estado de natureza, tivesse o poder para pôr em execução essa lei [...]" (LOCKE, 1999, cap.II §7). O poder (e o direito) de punir, no estado de natureza, o transgressor da lei natural, e que apela directamente à faculdade humana de julgar é, no entanto, denominado por Locke de "poder executivo". No estado de natureza, cada indivíduo é o "executor da lei natural" (II §8). É deste direito, e deste "poder executivo da lei natural" (II $\S 13)$, que se deriva o poder executivo do Estado político. Locke não separa o poder judicial do poder executivo porque na sua origem aqueles dois poderes não podem ser distintos. A execução da lei natural é correlativa e consubstancial ao julgamento da sua putativa transgressão. O indivíduo no estado de natureza é simultânea e necessariamente executor e juiz.

Como sublinha Peter Laslett $\left(1988\right.$, p. 97) ${ }^{1}$, o poder e o direito executivo no estado de natureza é "judicial na sua natureza, pois é o pronunciamento e a aplicação de uma lei, a lei natural que é a lei da razão". A acção execu- tiva no estado de natureza é justificada por Locke em torno de argumentos que se tornariam lugares-comuns nos escritos sobre o poder judicial: "todo o homem, no estado de natureza, tem o poder de matar o homicida, não só para impedir aos outros o cometimento de um tal delito, que nenhuma reparação pode compensar, mas também para desviar os homens das tentações do criminoso" (II $\S 11$; ver II §18). Em suma, o poder executivo é justificado pelas propriedades da punição e da dissuasão, algo que sugere a impossibilidade de separar poder judicial de executivo. Poder judicial e poder executivo confundem-se na acção executiva resultante da condição humana no estado de natureza. Mais: o estado de natureza que convoca o exercício do poder executivo individual é definido por Locke como aquela condição da qual está ausente "um juiz comum com autoridade" (II §19). Poderia dizer-se que o poder executivo e judicial está nas mãos de cada um dos indivíduos pela razão de a função do poder judicial não ser cumprida por nenhuma autoridade central comum. Em parte devido a esta confusão necessária, Locke admite as "inconveniências" da vida no estado de natureza. Afinal, tal estado obriga os homens a ser "juízes em causa própria", do qual facto "não se seguirá senão confusão e desordem" (II §13; cf. II §127); a instituição do governo civil aparece como o remédio para o conflito que inevitavelmente reinará no estado de natureza.

O fim do tumulto que preside ao estado de natureza chega com a institucionalização de um "juiz comum" para o qual todos os homens possam apelar para dirimir conflitos e transgressões da lei. A existência de um juiz comum com "autoridade suficiente", e "imparcial" na aplicação da lei comum a todos, revoga a legitimidade do exercício individual do poder executivo (e, poderíamos dizer, do exercício individual do poder judicial) (II §1920). Se os homens se unem na sociedade política, isso se deve ao desejo de abandonarem o "estado de guerra"; e se o "estado de guerra" tinha como uma das suas causas principais a assunção de todos e de cada um do exercício do poder executivo, então é lógico que a pacificação da convivência humana implique a desistência do exercício individual do poder executivo e a institucionalização de (e obediência a) um "juiz comum". . $\mathrm{O}$ homem pode finalmente viver em paz e em liberdade porquanto pode finalmente viver sob as leis: "em todos os estados de criaturas viventes e capazes de leis, aonde não há lei não há liberdade: porque a liberdade deve estar isenta da restrição e violência dos outros, o que não pode acontecer aonde não há lei” (II §57 e II §87-89). É esta a origem do poder executivo e legislativo da sociedade política. A sua separação é consequência do imperativo de conservação da liberdade individual, finalidade de toda a sociedade política legítima. Segundo Locke, é preciso, portanto, separar o poder executivo do poder legislativo de modo a impedir a concentração de autori- 
dade num único agente político. A tirania pode, por isso, ser definida de acordo com a acumulação do poder executivo e do poder legislativo num mesmo agente, pois deste modo repete-se a situação em que alguém é juiz em causa própria - nomeadamente o tirano; por outras palavras, a condição de imparcialidade na aplicação das leis ou na sua execução não está garantida (II §90-93).

Porém, Locke não pretende operar uma separação paritária dos poderes legislativo e executivo. Para o autor inglês, o poder legislativo adquire a posição cimeira na organização do Estado. Apenas exige que o órgão detentor do poder legislativo governe "segundo as leis estabelecidas, promulgadas, e conhecidos pelo povo, e não por decretos extemporâneos, por juízes indiferentes e rectos para decidirem as controvérsias segundo essas leis [...]” (II §131). O carácter supremo do poder legislativo de Locke apenas indica a prioridade do governo das leis sobre o governo da execução arbitrária. O lugar dos "juízes indiferentes e rectos" não pode ser ameaçado pela hipotética pressão do agente legislativo. Apesar de ver conferida a sua superioridade, o poder legislativo não pode reclamar a absorção do poder executivo (II §144-145, 150$152)^{3}$. E, no entanto, Locke não admite a hipótese de um poder judicial elevado à categoria de sede de resolução de conflitos entre os diversos poderes. O poder de julgar, após o estabelecimento da sociedade política, é cedido ao todo da sociedade e, em termos constitucionais, é entregue ao poder legislativo (II §87-89). É este último que obtém o estatuto de juiz, depois do indivíduo, na sua dupla qualidade de executor e de juiz, prescindir desse direito natural de maneira a abandonar o estado de natureza. Não existe, portanto, um poder judicial "independente" (KILCULLEN, 1992, p. 158; TULLY, 1993, p. 20, 302).

\section{Montesquieu e o Poder Judicial}

Como já foi referido, Montesquieu, em Do espirito das leis, inicia a sua reflexão sobre o poder judicial num contexto muito específico. O livro que inclui as primeiras observações relativas ao poder judicial intitula-se $D a$ as leis que formam a liberdade política em sua relação com a constituição. Podemos dizer, então, que a reflexão de Montesquieu sobre o poder judicial está intimamente ligada a essa reflexão mais geral sobre a constituição política da liberdade (BINOCHE, 1998, p. 254-255).

Montesquieu abre a sua discussão propondo uma distinção clara entre a "independência" (ou a liberdade natural não-legal), por um lado, e a "liberdade política", por outro. O primeiro conceito de liberdade é inevitavelmente associado ao agir de acordo com a vontade individual, sem qualificações. Mas num regime político esta liberdade é absurda. A condição política do homem obriga a uma redefinição da liberdade. A "liberdade política", numa primeira formulação, consiste "em poder fazer o que se deve querer e em não ser forçado a fazer o que se não deve querer". A liberdade numa sociedade com leis é, portanto, "o direito de fazer tudo o que as leis permitem; e se um cidadão pudesse fazer o que elas proíbem, ele já não teria liberdade, porque os outros também teriam este poder" (MONTESQUIEU, 2000, livro XI, cap.3). Segundo esta primeira tentativa de definição, Montesquieu apresenta a liberdade política como a faculdade de agir de acordo com a vontade individual na esfera pessoal determinada e circunscrita pelas leis.

Contudo, Montesquieu depressa encontra uma dificuldade. Se a liberdade política se contrapõe à liberdade natural (ou "independência"), então é preciso ponderar que regimes políticos sustentam a liberdade. Segue-se a conclusão: "A liberdade política só se encontra nos governos moderados". Mas a conclusão torna-se imediatamente provisória: "Mas ela nem sempre existe nos Estados moderados; só existe quando não se abusa do poder; mas trata-se de uma experiência eterna que todo o homem que possui poder é levado a dele abusar; ele vai até onde encontra limites" (XI, 4). Neste passo, Montesquieu acrescenta mais um critério para a presença da liberdade política. Uma constituição é livre, não necessariamente na medida em que está associada a uma forma de governo moderada, mas apenas quando a moderação do poder político (mesmo de uma constituição dita moderada) é obtida através de limitações do abuso a que o seu exercício está sujeito. A liberdade já não consiste somente no respeito pelas leis no decurso das minhas acções, mas também na inviolabilidade das protecções conferidas aos indivíduos pelas leis. Assim, a liberdade é uma vez mais redefinida como "esta tranquilidade de espírito que provém da opinião que cada um tem sobre a sua segurança; e para que se tenha esta liberdade é preciso que o governo seja tal que um cidadão não possa temer outro cidadão" (XI, 6). É condição necessária da liberdade política que a constituição limite o poder através do poder, que eles se contraponham e se equilibrem. Para tal, é preciso que os poderes estejam divididos ou separados, ou se se quiser, que não estejam concentrados na mesma agência política.

De acordo com Montesquieu, em todos os Estados existem três poderes distintos: o poder legislativo, o "poder executivo das coisas que dependem do direito das gentes" e o "poder executivo daquelas que dependem do direito civil". Aparentemente, nada mudou relativamente à tripartição de Locke. Inclusivamente, o primeiro tipo de poder executivo apresentado por Montesquieu pode ser identificado com o poder federativo de Locke. Por outro lado, Montesquieu ainda insiste no grande dualismo entre "legislativo" e "executivo", embora opere uma bifurcação no interior do poder executivo. Mas ele está bem familiarizado com a obra dos seus predecessores. Por isso, 
logo a seguir especifica que o segundo tipo de poder executivo designa o poder que "castiga os crimes, ou julga as querelas entre os particulares". A especificação enunciada exige uma nova denominação: este tipo de poder executivo deve passar a ser conhecido, nas palavras de Montesquieu, por "poder de julgar". Assim, chegamos à moderna tripartição de poderes: o legislativo, o executivo e o "de julgar", ou judicial (XI,6).

$\mathrm{O}$ modo de averiguação do grau de liberdade de cada Estado implica um exame da distribuição de poderes na constituição. Como é universalmente sabido, Montesquieu nega a qualidade da liberdade a todas as constituições que reúnam o poder legislativo com o executivo, o poder judicial com o executivo ou o judicial com o legislativo, para não mencionar as constituições tirânicas nas quais o mesmo agente político concentre e monopolize os três poderes. Mas é interessante notar que Montesquieu refere que um governo pode ser "moderado" (mas não propriamente "livre") quando o "príncipe" detém o poder legislativo e executivo, mas entrega o poder judicial aos "seus súbditos" (XI,6). Isto parece significar que a separação e distribuição de poderes não se trata de um artifício constitucional indiferenciado. A separação do poder judicial dos restantes poderes é mais necessária, se é lícito dizê-lo, do que a separação do poder executivo do legislativo. Tal sensibilidade da liberdade ao poder judicial só pode estar relacionada com a natureza desse mesmo poder (XI,11).

Para compreendermos a natureza específica do poder judicial convém não evitarmos uma distinção estabelecida por Montesquieu e que é muito reveladora da sua teoria do Estado. Para o autor todos os actos políticos do Estado são emanações da vontade, independentemente da sua proveniência. Mas enquanto a capacidade legislativa manifesta as "vontades gerais" do poder político, já a capacidade executiva manifesta as "vontades particulares" (XI, 6). Qualquer leitor percebe imediatamente a influência que esta distinção de Montesquieu teria sobre Rousseau. As "vontades gerais" correspondem às leis emitidas pelo poder legislativo; têm um carácter geral na medida em que dizem respeito a todos os cidadãos, sem discriminações ou especificações. Mas a execução da lei, ou aplicação da lei, pressupõe, quase por definição, a particularização da generalidade própria da lei. Dizemos particularização porquanto a execução ou a aplicação da lei ocorre num contexto, em circunstâncias, envolvendo pessoas, particulares, concre- tas e não abstractas, como o texto de qualquer lei que se preze concebe. A execução é a dimensão da discriminação, nem que seja da discriminação das circunstâncias concretas onde a execução se realiza.

Note-se que a distinção entre "vontades gerais" e "vontades particulares" corresponde à distinção entre poder legislativo e poder executivo. À primeira vista, o poder judicial não pode ser incluído, nem no domínio das "vontades gerais", nem das "vontades particulares". Mas, como vimos anteriormente, o "poder de julgar" é elaborado a partir de uma reflexão sobre o carácter dual do poder executivo. Neste sentido, poderíamos dizer que o "poder de julgar" corresponde à manifestação das "vontades particulares" do poder político. Montesquieu confirma este passo ao afirmar que o poder legislativo é a "vontade geral do Estado" e o poder executivo "a execução desta vontade geral". Somente o poder de julgar pode ser considerado como a vontade particular do Estado. Afinal, a actividade do julgamento implica e realiza a particularização da generalidade da lei, bem como a discriminação das circunstâncias e das pessoas. Num julgamento, seja de que espécie for, são pessoas particulares e situações concretas que estão em causa. A descida da generalidade da lei à particularidade da sua aplicação tem o seu lugar mais cru, e, para alguns, mais digno, na sessão do tribunal. É aí que o poder é exercido sobre um particular. Ora esta consideração, por mais banal que possa parecer, é extraordinariamente significativa. Num Estado, o poder político, na sua vertente mais decisiva, e, porventura, mais coerciva ou violenta, aproxima-se do cidadão no grau mais intrusivo possível precisamente enquanto poder judicial. Daí que o poder de julgar seja, no dizer de Montesquieu, "tão terrível entre os homens" (XI,6). É “tão terrível" porque a sua proximidade é total ${ }^{4}$, a sua intrusão é radical, e a sua violência (ou coerção) é extraordinária.

Montesquieu cita Cícero para confirmar que "a força da lei só consiste no facto de estatuir sobre todos". Mas a descrição tão recorrente do carácter geral e abstracto da lei não é apenas uma descrição académica e de manual. Do ponto de vista do cidadão, os actos do poder legislativo - as "vontades gerais" - também são abstractos e distantes por serem gerais. Em nenhuma outra situação se coloca o cidadão numa relação tão solitária com o Estado. Enquanto poder legislativo, o poder político ainda está distante, não sendo muito mais do que uma abstracção, pelo menos do ponto de vista da cidadania comum. Mas o mesmo 
não é verdade quanto à experiência de sujeição ao poder judicial. O risco da injustiça nunca adquire proporções tão individualmente trágicas como no poder judicial. É por esta razão que Montesquieu aprecia tanto o julgamento por júri praticado na Inglaterra. Em Inglaterra, o poder de julgar não é dado a um "senado permanente", mas é antes "exercido por pessoas tiradas do seio do povo". Por intermédio desta prática, o tribunal dura apenas "o tempo que a necessidade requer". No entender de Montesquieu, a grande vantagem do julgamento por júri inglês consiste na sua, digamos assim, desinstitucionalização, ou, mais rigorosamente, na possibilidade de passar de uma instituição permanente e visível para uma instituição intermitente, provisória e, portanto, invisível. A "necessidade" exige o regular funcionamento do poder judicial, mas o julgamento por júri permite a desmaterialização provisória da instituição quando cessa essa mesma "necessidade". Conclui Montesquieu: em Inglaterra, o poder de julgar, "como não está ligado nem a um certo estado, nem a uma certa profissão, torna-se, por assim dizer, invisível e nulo. Não se têm continuamente juízes sob os olhos; e teme-se a magistratura, e não os magistrados" (XI, 6).

Contrastando a prática inglesa com a prática francesa, que Montesquieu tão bem conhece ${ }^{5}$, o autor vê no julgamento por júri a mesma eficácia necessária, mas também uma atenuação do terror invocado inevitavelmente pelo exercício do poder judicial. Como o júri é seleccionado do povo, e não é prerrogativa de uma classe profissional ou de um Estado social (como era em França), o cidadão comum não contempla quotidianamente nenhum grupo de potenciais opressores. Para além de ser desmaterializado, o poder judicial em Inglaterra é despersonalizado: "temese a magistratura, e não os magistrados". A proximidade terrível do poder judicial é agravada se se acrescentar a personalização do poder. Despersonalizado, o poder judicial pode adquirir algum carácter de generalidade que por natureza não possui. Despersonalizado, o poder judicial pode interpor alguma distância entre si e o cidadão. Torna-se invisível e nulo. O risco da injustiça é atenuado, ou, mais rigorosamente, a percepção de possível injustiça tem de ser atenuada tanto quanto possível, sem pôr em causa a integridade da instituição, aos olhos do cidadão comum. Sendo a manifestação das "vontades particulares", o poder tem ser organizado da forma menos particular possível. Mais: o poder judicial tem de ser politicamente neutralizado, ou na expressão de Montesquieu tornar- se "nulo". A sua acção deve seguir o funcionamento de um puro procedimento mais ou menos previsível. Os juízes são apenas "a boca que pronuncia as palavras da lei"; são "seres inanimados que não podem moderar nem a sua força, nem o seu rigor" (XI.6). Montesquieu não identifica os juízes com a "boca" das leis ou com "seres inanimados" porque lhe agrada uma qualquer concepção positivista da relação entre o julgamento e a lei; não o faz por não reconhecer o lugar da interpretação da lei no sistema judicial; fá-lo por reconhecer até onde pode chegar a latitude dada ao juiz quando é investido do papel de intérprete da lei e a ameaça que isso representa ${ }^{6}$.

Qual é o propósito de todas estas recomendações e preferências? A defesa da liberdade. Pois se a liberdade é a tranquilidade que provém da opinião que cada um tem da sua própria segurança, e se para garantir essa tranquilidade é necessário organizar o poder político de forma a que nenhum cidadão receie os restantes, quer colectiva, quer individualmente, então o poder judicial terá de sofrer a neutralização (política) descrita. "Esta segurança nunca é mais atacada do que nas acusações públicas ou privadas. Assim, é da excelência das leis criminais que depende principalmente a liberdade do cidadão" (XII, 2). Era um "grande privilégio" de todo cidadão romano só poder ser julgado pelo povo, especialmente nas províncias, já que fora de Roma a alternativa era ser submetido "ao poder arbitrário de um procônsul ou de um propretor" (XI,19). A este privilégio Montesquieu associa a liberdade dos cidadãos romanos. Por quê? É óbvio que trocar um só homem (procônsul) pelo povo como agente que profere o juízo determinante, em princípio, não resolve o problema do apuramento da justiça. Mas ao substituir um homem concreto, visível, reconhecível, por um grande grupo de homens, procede-se à despersonalização e, se é lícito dizê-lo, à generalização do poder judicial. Com esta mudança, o cidadão romano "não sentia a tirania" (XI, 19, os itálicos são meus). O juízo popular pode ser tão injusto quanto o de um procônsul; mas a tirania de um e de outro não se sente com a mesma intensidade. O homem receia recear um outro homem; ele receia que "o homem faça violência ao homem" (XII, 3). O problema da liberdade, ou da opinião que se tem da segurança individual, é uma questão revestida de uma forte dose de subjectividade.

A separação de podedo ponto de vista do funcionamento normal, ou ideal, de uma sociedade democratica e liberal. res mais a neutralização do poder judicial são recomendações constitucionais de primeira ordem para garantir a socieda- 
de livre. A mais ligeira disfunção no sistema judicial tem, por isso, consequências dramáticas para a liberdade, para não falar na justiça. As deficiências no sistema judicial são necessariamente traduzidas para a cidadania como promotoras de arbitrariedade nas vidas e nas relações de todos. Por outro lado, a protecção do poder judicial relativamente às possíveis interferências do Estado, de grupos sociais, ou de pessoas particulares, visa garantir que o poder judicial não é ele mesmo promotor de arbitrariedade. É no poder judicial, mais do que em qualquer outro poder, que o cidadão do regime democrático e livre mais receia a existência, ou pelo menos a aparência, da arbitrariedade.

\section{A "crise da |ustiça"}

A consideração do problema da "crise da justiça" deve ter em conta o contexto político-constitucional no seio do qual esse problema se manifesta. A crise da justiça num regime democrático e liberal é com certeza diferente da crise da justiça num regime despótico ou até num regime que adopta concepções parciais de democracia ou de liberalismo. Porém, nos nossos tempos a referência à crise da justiça em geral diz respeito às deficiências do sistema judicial do ponto de vista do funcionamento normal, ou ideal, de uma sociedade democrática e liberal. A "justiça" está em "crise" quando não protege devidamente os direitos individuais, nem os direitos que assistem as associações, instituições e outros corpos que compõem o tecido social. Está em crise a justiça quando a sua ineficiência bloqueia a actividade económica do mercado; está em crise quando o lugar ocupado pelo sistema judicial cai sob a suspeita de ilegitimidade. Por vezes, fala-se de uma justiça em crise quando se aponta as falhas de leis específicas ou da estruturação jurídica dos processos penais e dos procedimentos que regulam a actividade judicial. Mas numa sociedade livre, na qual os poderes estão separados, é preciso responsabilizar correctamente os poderes. Neste último caso, a responsabilidade recai sobre o poder legislativo, e não sobre o poder judicial. Este é apenas o lugar no qual se manifestam as deficiências legislativas.

A sociedade livre moderna adquiriu uma tal complexidade que seria de esperar um aumento exponencial do recurso à justiça. A complexificação das relações sociais, económicas e até políticas, teria inevitavelmente este correlato. $\mathrm{O}$ recurso à justiça, sempre uma necessidade, tornou-se uma necessidade universal e premente. Montesquieu informa-nos que nos despotismos, "todas as oportunidades de disputa e de processo são [...] reprimidas" (VI,1). Poderíamos dizer que o contrário é verdade nas sociedades democráticas e liberais. Nelas, as "oportunidades de disputa e de processo" são interpretadas à luz do exercício de direitos. E o exercício dos direitos tende a ser aplaudido como a acção que mais corresponde ao espí- rito democrático e até como o mais inequívoco sintoma de cidadania. Não nos pronunciaremos sobre a absoluta correcção deste juízo democrático. Mas da perspectiva do regime despótico vemos como esse constitui um argumento a ponderar. No despotismo, diz Montesquieu, a queixa judicial, enquanto tal, é reprimida. O exagero nas queixas, a "paixão pelas queixas", é, no despotismo, algo "bastante perigoso", pois supõe "um desejo ardente de fazer com que a justiça seja feita, um ódio, uma acção no espírito, uma constância em prosseguir" (VI, 2). Assim, o juízo democrático já exposto é parcialmente confirmado por Montesquieu: o exercício dos direitos, através do recurso à justiça, revela "um desejo ardente de fazer com que a justiça seja feita". Mas não é só isso que revela, como vimos. Revela "ódio", "acção no espírito", "constância em prosseguir", isto é, revela que as paixões que movem os cidadãos não são esmagadas pelo medo, nem pelo medo dos outros cidadãos, nem pelo medo do Estado. O cidadão livre pode incorrer neste vício que consiste na "paixão pelas queixas", mas essa paixão demonstra que ele vive em liberdade e que não é impotente. Os súbditos do déspota sabem que "o magistrado não deve ouvir falar deles e que a sua segurança está na sua nulidade". O cidadão livre, pois, sente-se seguro. "Os homens são todos iguais no governo republicano; são iguais no governo despótico: no primeiro, porque são tudo; no segundo, porque não são nada" (VI, 2).

É perfeitamente coerente com o espírito da complexa sociedade democrática e liberal que se recorra ao sistema judicial com abundância e por um sem número de razões. Mas o recurso incessante e avassalador ao sistema judicial não se deve apenas à asserção dos direitos individuais ou à complexificação das relações sociais e económicas. Num Estado moderno, democrático e liberal, o poder judicial pretende ser total, isto é, pretende ser a sede de resolução de todos os conflitos, quer os que se materializam entre a sociedade e o indivíduo, quer os que afectam as relações interindividuais. Não quer dizer que não se concebam formas de resolução dos conflitos que possam realizar-se fora do circuito formal que tradicionalmente define o poder judicial. Mas o poder judicial não resigna a sua responsabilidade sobre a regulação destas vias informais de resolução de conflitos. A ambição total do poder judicial tem várias causas ou motivos histórico-políticos, mas uma delas é, sem dúvida, a inscrição concreta da lógica da cidadania inerente ao Estado moderno, democrático e liberal. Supor que os cidadãos podem resolver os seus diferendos mais agudos no exterior do poder judicial organizado seria conceder que as leis do Estado não abrangem todos os cidadãos indistintamente e por igual.

O exemplo clássico dos duelos é bastante ilustrativo. Afinal, o duelo foi durante muito tempo a forma de resolução de conflitos que conscientemente se colocava à margem do poder judicial organizado. Mais: vários foram os reis que promulgaram e confirmaram éditos de morte con- 
tra os duelistas. Mas ainda assim esta prática perdurou. Aparentemente, a solução dos nossos dias parece ser inevitável: incluir como prerrogativa do poder judicial a resolução de atentados (reais ou imaginados) à honra e ao "bom-nome" dos indivíduos. Assim, o problema do duelo parece ter uma causa puramente legislativa e não propriamente judicial. Mas a reflexão de Cesare Beccaria permite-nos duvidar de que a causa do problema era apenas estritamente legislativa. Beccaria pergunta: "Por que razão o povo miúdo habitualmente não se bate em duelo como os grandes?" A sua resposta é elucidativa: "Não só porque não possui armas, mas porque a necessidade do sufrágio dos outros é menos comum na plebe do que naqueles que, sendo de categoria superior, se olham com mais desconfiança e inveja" (BECCARIA, 1998, X). Para realizar uma sociedade genuinamente democrática, isto é, igualitária, não basta que as leis, no seu texto, se dirijam a todos os cidadãos igualmente. É preciso que todos os cidadãos se submetam à resolução dos conflitos na sede do poder judicial. É preciso, pois, que todos os cidadãos, sem excepção, percepcionem a autoridade do poder judicial como genericamente suficiente, e que este poder seja interpretado como o lugar mais digno e razoável da reparação das injustiças e das afrontas. A mediação dos conflitos operada pelo poder judicial enquanto "boca" das leis representa e afirma que cada homem, numa sociedade democrática e liberal, não teme um outro cidadão, mas apenas as leis. Institucionaliza a proposição segundo a qual "o temor pelas leis é salutar, mas fatal e fecundo de crimes é o temor do homem pelo homem" (BECCARIA, 1998, XLI), ou se se quiser, a liberdade liberal. A asserção total do poder judicial é o meio através do qual se neutraliza a personalização do conflito, cuja propensão é para trazer consigo uma visão anárquica (como nas diversas concepções do estado de natureza) ou aristocrática (por propiciar a consumação do direito do mais forte) de sociedade. Neste sentido, as dificuldades e assimetrias de acesso ao poder judicial constituem um factor de anarquização da sociedade democrática e liberal. A crise da administração da justiça que implique a negação da presença total do poder judicial, quer se deva a razões de ordem financeira, logística, ou outra, representa uma ameaça de primeira ordem à integridade da sociedade moderna, democrática e liberal.

Assim, a par da crescente e inevitável judicialização da sociedade, deparamo-nos com dificuldades no fornecimento dos, e no acesso aos, serviços judiciais. Porém, a lógica das democracias liberais contemporâneas obriga à manutenção da harmonia entre "as necessidades e os meios". Para Montesquieu, é tão avesso à conveniência geral de uma sociedade livre não ser consequente com a proposição segundo a qual "quando sou forçado a pleitear, é necessário que eu possa pagar um advogado", como é negar que "quando estou doente, preciso poder conse- guir um médico" (VII,1). A desigualdade no acesso à justiça não é, pois, comparável, a todas as outras formas de desigualdade. Ela é especialmente grave porquanto simboliza a desigualdade do direito num regime político que assenta incontornavelmente na igualdade do direito, mais do que em qualquer outra forma de igualdade. Isto é especialmente verdadeiro numa época como a nossa, na qual em muitos domínios reina a ignorância da lei. A ignorância da lei é inevitável porque a crescente complexificação das sociedades contemporâneas trouxe consigo a multiplicação das leis, o que torna impossível o conhecimento pleno da lei. A nossa sociedade é a sociedade da omnipresença dos advogados, dos especialistas das leis que a troco de um vencimento esclarecem o cidadão ignorante das leis, em cujo processo de feitura (teoricamente) participou.

Outra problemática que tem alimentado o discurso contemporâneo sobre a crise da justiça, ou pelo menos sobre as mudanças no sistema de justiça, está também ligada à judicialização da sociedade. Perante o recuo em algumas matérias do poder legislativo (e do poder executivo), e perante a crescente auto-interpretação da cidadania democrática nos termos da linguagem dos direitos individuais, em alguns Estados tem sido muito intenso o chamado "activismo judicial". A actividade jurisprudencial tem permitido em alguns casos a substituição do poder legislativo, noutros a sua ultrapassagem. Se é verdade que muitos vêem nesta tendência uma melhoria qualitativa da protecção dos direitos individuais, e, portanto, uma melhoria da qualidade da cidadania, também não é possível ocultar os riscos que a mesma tendência contém.

\begin{abstract}
À medida que os julgamentos dos tribunais se multiplicam nas monarquias, a jurisprudência toma decisões que às vezes são contraditórias, porque os juizes que se sucedem pensam de maneira diferente, ou porque as mesmas causas são bem ou mal defendidas; ou enfim por uma infinidade de abusos que se infiltram em tudo o que passa pelas mãos dos homens. É um mal necessário que o legislador corrige de vez em quando, como contrário até mesmo ao espírito dos governos moderados. Pois, quando somos obrigados a recorrer aos tribunais, isto deve vir da natureza da constituição e não das contradições e da incerteza das leis (MONTESQUIEU, 2000, livro VI, cap.1).
\end{abstract}

A partir da leitura de Montesquieu procuremos apurar algumas considerações gerais hipoteticamente válidas para a nossa contemporaneidade. Nesse sentido, é possível dizer que a prática conhecida por "activismo judicial" não é uma prática especificamente republicana, mas monárquica. Trata-se, como se pode extrair da citação reproduzida, de um "mal necessário", mas que, no entanto, deve ser 
corrigida pelo legislador, pois é contrária ao "espírito dos governos moderados". A tendência dos nossos dias para fossilizar as decisões jurisprudenciais quando estas se referem a assuntos que se deseja decidir de uma vez por todas traduz a propensão para aumentar o número de matérias cuja deliberação pública ou política, em sede do próprio sistema parlamentar, é implicitamente negada. Montesquieu vê em fenómenos semelhantes uma deturpação das funções do sistema judicial num regime político "moderado" ou, com mais razão ainda, num regime "livre". Se o sistema judicial é mais ou menos forçado a clarificar as "contradições" e a "incerteza" das leis, isso se deve sem dúvida às falhas do poder legislativo; mas entretanto a divisão de tarefas e responsabilidades dos diversos poderes vê-se significativamente alterada. Essa alteração pode não ser neutral no que diz respeito ao sentido do próprio sistema político; a promoção do sistema judicial a quase legislador, bem como a constatação do hiato entre a sua fonte de autoridade e as suas (novas) prerrogativas, levantam o problema óbvio da legitimidade do sistema como um todo, por um lado, e o da inversão do conceito de cidadania democrática - mais concentrada na asserção judicial de direitos individuais, menos apostada na deliberação pública -, por outro.

Utilizando um outro vocabulário, dir-se-ia que as vontades "gerais" e as vontades "particulares" do Estado (e do cidadão) se cruzam no plano institucional e político com prejuízo das regras aceites do Direito Político democrático. Alexander Hamilton (HAMILTON; MADISON; JAY, 2003, n. 78), um dos proponentes da Constituição americana, nota que nunca pode haver "perigo" vindo do poder judicial para a "liberdade geral do povo" enquanto "permanecer verdadeiramente distinto tanto da Legislatura como do Executivo". A liberdade, continua Hamilton, "nada pode ter a recear do poder judicial isoladamente, mas teria tudo a recear da sua união com qualquer dos outros departamentos". Que cabe aos tribunais "esclarecer o sentido da lei", ninguém pode contestar. Mas quando o poder judicial pretende "exercer a VONTADE em lugar do JULGAMENTO" a consequência será a instituição da arbitrariedade no seu próprio seio. A "independência" do poder judicial vê assim confirmada a sua justificação e que consiste na protecção relativamente aos poderes restantes. As tendências dos nossos tempos podem levantar um problema inédito: a "independência" dos poderes vir a ser invocada para proteger o poder legislativo, ou, talvez, a sua sede tradicional (o Parlamento), da putativa invasão legislativa do poder judicial.
Esta confusão de funções e de faculdades é contrária à lógica da constituição da liberdade e, por conseguinte, dissipadora de legitimidade. A perda de legitimidade do sistema judicial, por pequena que possa ser, é sempre muito problemática do ponto de vista da justiça, da liberdade e da segurança.

A crise da justiça traz consigo a vontade de resolvê-la. Mas a vontade de reforma não é suficiente; é preciso também muita prudência, não vá o frenesim das soluções simples e precipitadas destruir os bens com que o sistema judicial moderno presenteou a liberdade política. Como escreve Montesquieu, "até mesmo os perigos da justiça são o preço que cada cidadão paga pela sua liberdade" (VI, 2).

Recebido em 11.07.2005.

Aprovado em 26.12.2005.

\section{Referências}

BECCARIA, C. Dos delitos e das penas. Tradução José de Faria Costa. Lisboa: Fundação Calouste Gulbenkian, 1998.

BINOCHE, B. Introduction à 'De l'Esprit des Lois' de Montesquieu. Paris: Presses Universitaires de France, 1998.

HAMILTON,A.; MADISON, J.; JAY, J. O Federalista. Tradução Viriato Soromenho-Marques e João C. S. Duarte. Lisboa: Colibri, 2003.

KILCULLEN, J. Locke on political obligation. In: CHAPPELL, V. (Ed.). John Locke: political philosophy. Londres: Garland, 1992.

LASLETT, P. Introduction. In: LOCKE, J. Two treatises of government. Cambridge: Cambridge University Press, 1988.

LOCKE, J. Ensaio sobre a verdadeira origem, extensão e fim do Governo Civil. Tradução João Oliveira Carvalho. Lisboa: Edições 70, 1999.

MAGALHÃES, P. C. O Sistema Judicial em Portugal: ineficácia e ilegitimidade. In: BARRETO, A. Justiça em crise? Crises da Justiça. Lisboa: Dom Quixote, 2000, p. 411-424.

MANSFIELD, H. Taming the prince. The ambivelence of modern executive power. Baltimore: Johns Hopkins University Press, 1993.

MIRANDA, J. Crise de justiça e tribunais. In: BARRETO, A. Justiça em crise? Crises da Justiça. Lisboa: Dom Quixote, 2000, p. 253-262.

MONTESQUIEU, Barão de. O espirito das leis. Tradução Cristina Murachco. São Pualo: Martins Fontes, 2000.

TULLY, J. An approach to political philosophy: Locke in contexts. Cambridge: Cambridge University Press, 1993. 


\section{Notas}

1 Ver também Mansfield (1993, p. 193).

2 Para Locke, a desistência ou resignação do exercício individual do poder executivo aquando da formação da sociedade política não pode ser total. De outro modo o direito à revolução perderia o seu fundamento.

3 No pensamento de Locke, a teoria da "prerrogativa" executiva complica ainda mais a separação de poderes e a hierarquia de preeminência entre eles (II §159-168).

4 Sobre a proximidade do poder judicial, ver também Beccaria $(1998$, IV).

5 Montesquieu desempenhou durante muito tempo as funções de Président à mortier no importante Parlement de Bordéus, e, como se sabe, a mais importante tarefa dentre essas funções era precisamente a de juiz.

6 "Nos Estados despóticos, não há lei: o juiz é ele mesmo a sua própria regra. Nos Estados monárquicos, existe uma lei: e onde ela é precisa, o juiz segue-a; onde ela não o é, ele procura seu espírito. No governo republicano, é da natureza da constituição que os juízes sigam a letra da lei. Não há cidadão contra quem se possa interpretar uma lei quando se trata de seus bens, de sua honra ou de sua vida."

"Em Roma, os juízes sentenciavam somente que o acusado era culpado de um determinado crime, e a pena se encontrava na lei, como podemos ver em várias leis que foram feitas. Assim também, na Inglaterra, os jurados decidem se o acusado é culpado ou não do fato que lhes foi relatado, e se ele for declarado culpado o juiz pronuncia a pena que a lei inflige para este crime e para tanto ele só precisa ter olhos" (MONTESQUIEU, 2000, livro VI, cap. 3).

\section{Miguel Morgado}

mmorgado@fe.ucp.pt

Universidade Católica Portuguesa-UCP

Faculdade de Ciências Humanas

Palma de Cima

1649-023

Lisboa - Portugal 